\title{
MEDIATING ROLE OF ACCESS TO FINANCE ON THE RELATIONSHIP BETWEEN STRATEGIC ORIENTATION ATTRIBUTES AND SMES PERFORMANCE IN NIGERIA
}

\author{
Murtala Aminu Ibrahim \\ Bayero University Kano \\ Mohd Noor Mohd Shariff* \\ Universiti Utara Malaysia
}

\begin{abstract}
In spite of recognized significant contribution of SMEs to nations' economy, Nigerian SMEs performance is below expectation. This is because SMEs in Nigeria today faces severe limitations in financing, management skill, marketing, modern technology and technical expertise. The objective of this study is to investigate the mediating role of access to finance on the positive relationship between entrepreneurial orientation (EO), market orientation (MO), learning orientation (LO), technology orientation (TO) and SMEs performance in Nigeria. A sample size of 522 SMEs operating in Kano, Kaduna and Sokoto states of Nigeria were selected using stratified simple random sampling techniques. Partial Least Squares-Structural Equation Modelling was used to analyze the data. Hence, the data analysis was conducted using SmartPLS 3.0. The results of path analysis indicate that access to finance mediates the positive relationship between MO, LO, TO and the performance of small and medium enterprises in Nigeria. This is an important additional explanation for the existence of the relationship between these strategic orientations and firm performance. The results further suggest that SMEs need to use their strategic activities to improve their ability to obtain finances in order to perform well. Finally, recommendations for further research are also discussed.
\end{abstract}

Keywords: SMEs; Strategic Orientation; Nigeria; Access to Finance; Firm Performance.

\section{INTRODUCTION}

Over the years, Small and Medium Enterprises (SMEs) have gained increasing attention all over the world. This is because they play a significant role in improving economic growth and development, ranging from poverty reduction to employment creation (Small and Medium Enterprises Development Agency of Nigeria [SMEDAN], 2012). In Nigeria, the contribution of SMEs to GDP and employment stands at $46.54 \%$ and $25 \%$,

\footnotetext{
*Corresponding author: School of Business Management, College of Business, Universiti Utara Malaysia, 06010 UUM Sintok, Kedah, Malaysia. E-mail: mdnoor@uum.edu.my
} 
respectively (Ndumanya, 2013; SMEDAN, 2012). However, the contribution is below expectation and remains a significant issue, more especially as the country aims to be among the big economies by 2020 . Certainly, performing SMEs will play an important role in achieving this objective. Therefore, it is important to examine the factors that may improve performance of SMEs in Nigeria.

According to Barney (1991) strategic orientations are organizational cultures representing intangible resources for the firms. Similarly, Gatignon and Xuereb (1997) conceptualize strategic orientations as the strategic activities carried out by the firm to develop and improve firm activities for superior performance. Therefore, the interplay between different strategic orientations may provide firms with competitive advantages which can lead to better performance (Hult, Ketchen, \& Slater, 2005). A number of studies have shown that EO, MO, LO and TO are the most important firm resources that can give firms a competitive advantage and lead to better performance (Mu \& Di Benedetto, 2011; Salavou, 2010).

For instance, exponents of EO suggest that firms promoting entrepreneurial activities are better able to make their operations fit in a dynamic business environment which will have a positive effect on firm performance (Mu \& Di Benedetto, 2011; Rauch, Wiklund, Lumpkin, \& Frese, 2009). Literature on marketing suggests that the concept of MO is of great importance in affecting the culture of the organization and creating a behavior that will provide the firm with a sustained competitive advantage (Grawe, Chen, \& Daugherty, 2009). Furthermore, it has been argued that due to the dynamic nature of the business environment, ability to learn more quickly than competitors may be the only source of sustainable competitive advantage. This indicates the importance of LO in developing new knowledge and transferring information into knowledge (Eris \& Ozmen, 2012). The importance of technology and innovation in business cannot be over-emphasized, firms that are technologically oriented will have long-term success as they create and utilize new technological solutions, products and services (Hakala \& Kohtamaki, 2011). Therefore, it has been argued that EO, MO, LO and TO could be an important measures of the way the SMEs are organized and its performance could be enhanced through acquiring external financial resources (Aminu \& Shariff, 2014).

However, despite the notable importance of strategic orientations, prior studies have only investigated the effect of a single (Mahmoud, 2011; Su, Xie, \& Li, 2011); or a combination of few strategic orientations (Mahmoud \& Yusif, 2012; Wang, Chen, \& Chen, 2012). Others investigated the direct relationship between EO, MO, LO, TO and SMEs access to finance (Aminu \& Shariff, 2015). There is limited empirical evidence investigating whether access to finance by SMEs can mediate the relationship between these strategic orientation and the performance of SMEs as proposed by Aminu and Shariff (2014). 
The remainder of the paper is structured as follows: Firstly, previous literature on EO, MO, LO, TO and firm performances were reviewed. The conceptual model in Figure 1 and the set of the study hypotheses were also presented. Then, there follows the methodology used in this research work and data analysis. The paper ends with a discussion of the implications, the limitations, and future research.

\section{LITERATURE REVIEW}

\subsection{SMEs Performance}

In several small business literatures, SMEs' performance has been studied by a number of researchers. Most of these researches have focused on investigating SMEs' performance determinants, in which several variables have been identified. According to Neely, Gregory and Platts (1995), firm performance is a concept that is often discussed in various studies, but rarely has a single definition. They argue that firm performance is the process of quantifying actions of a business firm that leads it to achieve its goals and objectives. From a business perspective, firms achieve their objectives if they perform in satisfying their stakeholders and customers' needs more than their competitors. It also indicates how well the management manages the firm's resources (Moullin, 2007). However, Sandberg (2003) argues that the performance of SMEs is the ability to survive, grow and contribute to the creation of employment and alleviate poverty.

Though, to look at SMEs' performance, it is important to understand what constitute the SMEs in the context of Nigeria. This is because the definitions for SMEs vary from country to country based on the countries' guidelines for defining SMEs (Bouri, Breij, Diop, Kempner, Klinger, \& Stevenson, 2011). In Nigeria, SMEs are defined based on the number of employees and total assets value excluding land and building. However, if there is a clash on classification between employment and assets criteria, the employment-based definition should take priority (SMEDAN, 2012).

Table 2.1: Definition of SMEs in Nigeria

\begin{tabular}{cccc}
\hline \hline S/N & Size Category & Employment & Assets (Excluding land and building) \\
\hline 1 & Small Enterprise & 10 to 49 & N5m to less than N50m \\
2 & Medium Enterprise & 50 to 199 & N50m to less than N500m \\
\hline
\end{tabular}

Source: SMEDAN (2012).

Therefore, this study adopts the definition above, because it is more recent and accommodates various business firms, especially with regards to turnover compared to previous definitions (SMEDAN, 2012).

Many studies on firm performance have used several firm resources to investigate factor influencing SMEs' performance. For example, several studies used EO to investigate firm 
performance (Fatoki, 2012; Mutlu \& Aksoy, 2014). Likewise, several studies have used MO to examine firm performance (Huhtala, Sihvonen, Frösén, Jaakkola, \& Tikkanen, 2014; Suliyanto \& Rahab, 2012). Other studies have considered LO as a variable that improves firm performance (Farrell, Oczkowski, \& Kharabsheh, 2008; Hakala, 2013). Finally, several studies have used TO to investigate firm performance (Hakala \& Kohtamaki, 2011; Hortinha, Lages, \& Lages, 2011; Voss \& Voss, 2000).

\subsection{EO and Firm Performance}

Research in the past has recognized the relevance of EO to the performance of the firm (Zahra \& Covin, 1995). The most widely used meaning of EO is focused around the work of Miller (1983), advanced further by Covin and Slevin (1989) and numerous others, and later enhanced by Lumpkin \& Dess (1996). EO indicates whether business firms take decisions that are risky, proactive and innovative in achieving its objectives (Covin \& Slevin, 1989). Similarly, EO can be seen as a particular process through which firms relate to opportunities and activities that lead to new business opportunities (Lumpkin \& Dess, 1996). These processes, actions and intentions include risk taking behavior, ability to act autonomously and proactively, in innovative and aggressive ways towards competitors (Lumpkin \& Dess, 2001). According to Wiklund and Shepherd (2005), EO is a firm's strategic ability to capture specific aspects of decision-making, methods and business practices. Thus, firms with sound EO can have the ability to discover and use new market opportunities. Covin and Miller (2014) refer to risk taking as high financial leverage. Whereas innovativeness is the ability of the firm to come up with new products and ideas, the strength of this ability is usually measured by the actuality of these ideas as products (Covin \& Miller, 2014). Lastly, proactiveness is looking into the future based on environmental demand, where firms look out for opportunities and develop new products to gain the advantages of pioneering and leading the competitors (Hughes \& Morgan, 2007).

EO as a strategic resources of a firm found to relate positively with firm performance (Hakala \& Kohtamaki, 2010). Equally, study by Long (2013) found a positive relationship between EO and firm performance. Similar empirical findings show that the higher the firm's EO, the more the firm can achieve superior performance (Kraus, 2013; Roxas \& Chadee, 2013). An investigation on the relationship between EO and LO indicates that EO has direct effects on both profitability and growth (Hakala, 2013). Likewise, Brouthers, Nakos and Dimitratos (2014) findings indicate that SMEs have higher international performance when they have greater EO. Furthermore, the relationship between EO and business performance in Malaysia was found to be positively significant (Aziz, Mahmood, Tajudin, \& Abdullah, 2014). According to Laukkanen, Nagy, Hirvonen, Reijonen, and Pasanen (2013), EO has a positive influence on SMEs' growth both in Hungary and Finland through brand and market performance. The effect of EO on firm performance in Dubai was confirmed to be positively significant (Al-dhaafri \& Al-swidi, 2014). In contrast, some studies found no significant direct relationship between EO and 
firm performance (Baker \& Sinkula, 2009; Stam \& Elfring, 2008). In the same view, the notion of a direct relationship between EO and firm performance seems to be empirically inconclusive. This can be seen in a study by Alegre and Chiva (2009) that found the direct influence of EO over firm performance is not significant. A replication study by Frank et al. (2010) found that EO does not have a substantial effect on firm performance, the study showed a possible adverse effect of EO on performance.

\subsection{MO and Firm Performance}

There are different perspectives to MO, although all the perspectives put the customer at a center stage. The perspectives also recognize the importance of information, functional coordination, responding to customer and protecting stakeholders' interest (Lafferty \& Hult, 2001). These MO perspectives include the decision making perspective (Shapiro, 1988), market intelligence behavior perspective (Kohli \& Jaworski, 1990), culture of the firm (Narver \& Slater, 1990), information perspective (Ruekert, 1992) customerorientation perspective (Deshpandé, Farley, \& Webster, 1993). However, there are some essential differences among these perspectives and numerous similarities that reflect what MO is. Based on these perspectives, Lafferty and Hult (2001) synthesized and integrated these perspective into cultural and managerial foci. Generally, MO as the implementation of marketing concept, has gained considerable attention in the firm performance literature (Dauda \& Akingbade, 2010).

According to Kara, Spillan, \& DeShields Jr. (2005) MO and small-sized firm performance is positively significant. The study concludes that MO is a significant predictor of business performance. Dauda and Akingbade (2010) indicate that small businesses that engage in $\mathrm{MO}$ activities recorded a superior performance compared to others that have not applied MO. Similarly, MO and performance relationship was found to be significant in a study of 356 SMEs in Malaysia (Idar \& Mahmood, 2011). Likewise, a study on SMEs in Ghana indicates a significant impact of MO on firm performance (Mahmoud, 2011). In Vietnam Long (2013) reports that MO has a significant positive effect on firm performance. In country comparison study, Laukkanen et al. (2013) report that in Finland and Hungary, MO influences firm growth through branding and market performance. Despite a notable influence of MO on overall firm performance, some past studies have reported effect of MO on only subjective performance (Farrell et al., 2008; Jaworski \& Kohli, 1993). While others reported positive relationship only on objective (Baker \& Sinkula, 2009; Nikoomaram \& Ma'atoofi, 2011). To this end, Mahmoud and Yusif (2012) found a significant positive effect of MO on both economic and non-economic performance. Subsequently, it can be concluded that the influence of MO on firm performance varies depending on the performance measure adopted in the study. In addition, despite the important of $\mathrm{MO}$ in predicting firm performance, some studies report no significant direct effect of MO on firm performance (Polat \& Mutlu, 2012; Suliyanto \& Rahab, 2012). 


\subsection{LO and Firm Performance}

Although the concept of LO can be found in several areas of research, including psychology, sociology and education, LO has become one of the principal strategic orientations in strategic management (Mavondo, Chimhanzi, \& Stewart, 2005). Slater and Narver (1995) argue that due to the inability of MO to predict firm performance, business firms need to be learning oriented if they want to be successful in the long-run. Similar to this argument, Farrell (2000) states that there is a need for business firms to facilitate learning in their firms. This is because LO is a source of competitive advantage. However, Slater and Narver (1995) contend that market-oriented firms must develop LO culture in order to face competition effectively. According to Baker and Sinkula (1999), LO is a set of organizational behavior that affects how business firms learn from their business environment and respond to the needs of the environment. In the same vein, LO is a firm valuable resource that influences the tendency of the firm to create and use knowledge (Farrell \& Mavondo, 2004).

A study of 449 entrepreneurs reports that firm performance is positively affected by LO culture of the firm (Kropp, Lindsay, \& Shoham, 2006). In trying to find a clear picture of whether businesses should focus more on LO or MO, Farrell et al. (2008) found LO significantly influences performance of international joint ventures although MO has more significant influence. In addition, Jiménez-Jiménez and Sanz-Valle (2011) investigate organizational learning process and its effect on innovativeness and performance. The study found that organizational learning has a positive influence on business performance. Mahmoud and Yusif (2012) report a positive significant relationship between LO and both economic and non-economic performance. Comparative study of SMEs in Hungry and Finland shows that the relationships between LO and firm performance vary across countries. The results suggest that while the direct relationship between LO and brand performance is positive among Hungarian SMEs, the relationship is negative among Finnish SMEs (Laukkanen et al., 2013). Similarly, Hakala (2013) examines the mediating role of LO and the study reports that LO has a direct effect on performance, more specifically firm growth and profitability and effect of EO on profitability is mediated by LO behaviors. A contrary result was reported by JiménezJimenez et al. (2008) found that organizational learning has no significant direct effect on performance. Also, Suliyanto and Rahab (2012) indicate that there is no positive effect of LO on firm performance. Similarly, Long (2013) studies the impact of strategic orientations on firm performance, the study found no significant relationship between LO and firm performance.

\subsection{TO and Firm Performance}

Another important element of strategic orientation is TO. Recently, TO has been focused on in several strategic orientation literature as one of the essential components that contributes to firm value delivery (Gatignon \& Xuereb, 1997). Ettlie, Bridges and 
O'keefe (1984) suggest that technology in a firm promotes creative effort of the firm. Achieving business goal lies on the ability of the firm to welcome new ideas and quick adaptation of new technologies (Hurley \& Hult, 1998). Technological superiority determines the acceptability of the product in the market because consumers prefer quality goods and services. Thus, firms that are committed to research and development, and that employ new technologies will undoubtedly achieve competitive advantage (Voss \& Voss, 2000). Therefore, TO is a firm's ability and willingness to develop technological mindset and utilize it in improving or developing products and services (Gatignon \& Xuereb, 1997).

Gatignon and Xuereb (1997) report a significant positive relationship between TO and innovation superiority and firm performance. Likewise, Gao, Zhou, and Yim (2007) reveal that TO positively affect firm profitability and product performance with average technological changes, while it has no significant effect on sales growth. However, the study indicates that with little technological turbulence, TO has a negative effect on business performance. Another result found that TO has significant positive influence on product performance, particularly in terms of newness of the product to customers (Salavou, 2010). Additionally, Mu and Di Benedetto (2011) found that TO has a significant effect on product commercialization performance. Similarly, Spanjol et al. (2011) report similar findings on the significant positive effect of TO on a firm's product innovation performance. According to Hoq (2009) and Paladino (2007), TO relates significantly to overall firm performance. In contrast, Voss and Voss (2000) found no significant effect of $\mathrm{TO}$ on both subjective and objective performance of a firm. In a study that examined the interplay between EO, TO and customer orientation, the results show that TO has no direct significant relationship with performance (Hakala \& Kohtamaki, 2010). Also Hortinha et al. (2011) report that TO does not affect performance directly.

\subsection{Access to Finance}

Financial capital is the most common type of resource that is relatively easy to convert into other types of resources. Hence, access to capital is important for small businesses' performance (Wiklund \& Shepherd, 2005). Access to finance is one of the critical issues responsible for gross low performance of SMEs in Nigeria. Therefore, having financial resources can enhance their performance (SMEDAN, 2012). Several studies have shown that a firm's superior performance is attributed to the ability of the firm to access required financial capital (Demir \& Caglayan, 2012; Turyahebwa, Sunday, \& Ssekajugo, 2013). However, access to finance is evidently depends on the firm's strategies (Cheng, Ioannou, \& Serafeim, 2014). It is apparent that firms with high entrepreneurial skills will have better access to resources, including financial resources (Mohammed \& Obeleagunzelibe, 2014). Similarly, firms that are market-oriented have been found to have positive influence on the firm's profitability (Baker \& Sinkula, 2009). In short, it is expected that market-oriented firms can generate high income, specifically with learning from the environment. Technological superiority is no doubt a good firm strategy that can improve 
ability to have more funds, since such firms can produce superior products that can compete favorably in the market and perform better (Aminu \& Shariff, 2015).

Based on this premise, it is expected that access to finance can be a mechanism through which EO, MO, LO, and TO positively relate to SMEs' performance. This is one of the important empirical contributions of this study because it offers a more nuanced explanation on how these strategic orientations affect firm performance. Although numerous studies (Baker \& Sinkula, 2009; Long, 2013) have explained that EO, MO, LO and TO influence firm performance. However, a lack of empirical evidence on the mechanisms, such as access to finance through which firm performance is affected. Hence, access to finance may provide the necessary explanation of how EO, MO, LO and TO enhance firm performance. In other words, this study posits that:

H1: Access to finance mediates the positive relationship between EO and performance of SMEs in Nigeria.

H2: Access to finance mediates the positive relationship between $\mathrm{MO}$ and performance of SMEs in Nigeria.

H3: Access to finance mediates the positive relationship between $\mathrm{LO}$ and performance of SMEs in Nigeria.

H4: Access to finance mediates the positive relationship between TO and performance of SMEs in Nigeria.

\section{METHODOLOGY}

Based on literature, strategic orientations are normally operationalized from the firm level perspective (Covin \& Slevin, 1989; Hortinha et al., 2011). In SMEs studies, the target respondents are usually the owner-managers, given that they have more knowledge regarding their enterprises' strategies and overall business situations (Zahra \& Covin, 1995). Therefore, the unit analysis of this study is firm level and the target respondents are SME owner-manager in Kano, Kaduna and Sokoto states of north-western Nigeria. This is in line with several studies on SMEs' performance (Hakala \& Kohtamaki, 2011; Nikoomaram \& Ma'atoofi, 2011).

This study follows a quantitative methodology, where numbers are used to represent the phenomenon being studied (Hair Jr., Black, Babin, \& Anderson, 2010). The study adopts a survey research design and is cross-sectional as data was collected at one time. The research model consists of six reflective constructs $\mathrm{EO}, \mathrm{MO}, \mathrm{LO}, \mathrm{TO}$, access to finance and firm performance. The study adapted measurements based on the previous studies relevant to the current research context (Churchill, 1979). The present study measures items on a seven-point Likert-scale ( $1=$ Strongly disagree; $2=$ Disagree; $3=$ Somewhat disagree; $4=$ Neither agree or disagree (Neutral); $5=$ Somewhat agree; $6=$ Agree; $7=$ Strongly agree). The items were adapted from previous studies, firm performance from 
Suliyanto and Rahab (2012), EO from Hakala and Kohtamäki (2011). MO from Suliyanto and Rahab (2012), LO from Farrell et al. (2008), TO from Spanjol et al. (2011) and access to finance from Martin, Cullen, Johnson and Parboteeah (2007).

The population in this study are the SMEs operating in the Kano, Kaduna and Sokoto states of north-western Nigeria. North-western Nigeria has the highest number of SMEs in the country, out of which 5,010 are small and medium (SMEDAN, 2012). The sample size for this study is 348 SMEs. This is obtained from the sampling formula by (Dillman, 2007). The sample was increased to 522 to avoid non-response problem and sample size error (Salkind, 1997). Samples were disproportionately selected randomly from each stratum of Kano, Kaduna and Sokoto based on the respective sample size (Sekaran \& Bougie, 2010). Using the list of SMEs (sampling frame) that were provided by SMEDAN, 522 copies of the questionnaire were administered on the randomly selected target respondents (SMEs owner-managers). Samples for each stratum were selected using a random number generated function in MS Excel 2010 (RAND) in line with (Saunders, Lewis, \& Thornhill, 2009).

The study used Partial Least Square Model to analyse the data. SmartPLS v3.0 (Ringle, Wande, \& Becker, 2014) was used to determine the outer model (reliability, convergent validity and discriminant validity) and inner model (significance of the path coefficients, coefficient determination, the effect size and predictive relevance).

\section{DATA ANALYSIS AND RESULTS}

\subsection{Common Method Bias Test}

There are several procedures and statistical techniques to treat common method variance. These include wording questions in reverse, clarity of questions or items, confidentiality of the respondents and statistical Harman's one-factor test (Podsakoff, MacKenzie, Lee, $\&$ Podsakoff, 2003). In this study, un-rotated factor analysis with seventy items of all the variables of the study revealed that no single factor accounted for more than $50 \%$ of the variance. The result produced 16 distinct factors and only $21.61 \%$ of the total variance was accounted by a single factor, indicating the absence of common method bias in this study. This is in line with Podsakoff et al. (2003) and Lowry and Gaskin (2014), who argue that common method bias is present when a single factor explains more than $50 \%$ of the variance.

\subsection{Evaluation of PLS-SEM Result}

After the checking and screening of the data, the next step was to assess the outer model and inner model (Hair Jr., Hult, Ringle, \& Sarstedt, 2013). PLS-SEM was used in this study to evaluate the outer model (measurement model) and the inner model (structural 
model). In other words, PLS-SEM was used to analyze the mediating results of this study. SmartPLS 3.0 by Ringle et al. (2014) was used to determine causal links among the constructs in these theoretical models.

\subsubsection{The Measurement Model}

Reliability and validity are the two main criteria used in PLS-SEM analysis to evaluate the outer model (Hair Jr. et al., 2013). The conclusion about the nature of the relationship among constructs (inner model) depends on the reliability and validity of the measures. The suitability of the outer model can be assessed by looking at: (1) individual item reliabilities, i.e., indicator reliability and internal consistency reliability using composite reliability (CR); (2) convergent validity of the measures associated with individual constructs using average variance extracted (AVE); and (3) discriminant validity using Fornell-Larcker criterion and the indicator's outer loadings.

Table 4.1: Loadings, Reliability and Convergent Validity Values

\begin{tabular}{|c|c|c|c|c|c|c|c|}
\hline Variables & Items & Loading & $\begin{array}{l}\text { Indicator } \\
\text { Reliability }\end{array}$ & $\begin{array}{c}\text { Cronbach's } \\
\text { Alpha }\end{array}$ & CR & AVE & $\begin{array}{c}\text { Discriminant } \\
\text { Validity? }\end{array}$ \\
\hline \multirow{5}{*}{ FP } & AFP1 & .85 & .73 & \multirow{5}{*}{.87} & \multirow{5}{*}{.91} & \multirow{5}{*}{.66} & \multirow{5}{*}{ Yes } \\
\hline & AFP2 & .87 & .76 & & & & \\
\hline & AFP3 & .87 & .75 & & & & \\
\hline & AFP5 & .63 & .40 & & & & \\
\hline & AFP6 & .82 & .68 & & & & \\
\hline \multirow{7}{*}{ EO } & BEO10 & .85 & .71 & \multirow{7}{*}{.88} & \multirow{7}{*}{.90} & \multirow{7}{*}{.57} & \multirow{7}{*}{ Yes } \\
\hline & BEO11 & .72 & .51 & & & & \\
\hline & BE012 & .66 & .44 & & & & \\
\hline & BEO2 & .76 & .57 & & & & \\
\hline & BEO3 & .80 & .64 & & & & \\
\hline & BEO4 & .68 & .47 & & & & \\
\hline & BEO9 & .82 & .68 & & & & \\
\hline \multirow{8}{*}{ MO } & CMO10 & .76 & .58 & \multirow{8}{*}{.88} & \multirow{8}{*}{.91} & \multirow{8}{*}{.54} & \multirow{8}{*}{ Yes } \\
\hline & CMO11 & .76 & .57 & & & & \\
\hline & CMO12 & .75 & .57 & & & & \\
\hline & CMO13 & .72 & .52 & & & & \\
\hline & СМO6 & .74 & .55 & & & & \\
\hline & CMO7 & .72 & .52 & & & & \\
\hline & CMO8 & .74 & .55 & & & & \\
\hline & CMO9 & .70 & .49 & & & & \\
\hline \multirow{5}{*}{ LO } & DLO1 & .78 & .61 & \multirow{5}{*}{.85} & \multirow{5}{*}{.89} & \multirow{5}{*}{.62} & \multirow{5}{*}{ Yes } \\
\hline & DLO2 & .86 & .74 & & & & \\
\hline & DLO3 & .87 & .77 & & & & \\
\hline & DLO4 & .76 & .58 & & & & \\
\hline & DLO5 & .63 & .40 & & & & \\
\hline \multirow{5}{*}{ TO } & ETO10 & .79 & .62 & \multirow{5}{*}{.93} & \multirow{5}{*}{.94} & \multirow{5}{*}{.64} & \multirow{5}{*}{ Yes } \\
\hline & ET011 & .77 & .59 & & & & \\
\hline & ETO3 & .84 & .71 & & & & \\
\hline & ETO4 & .86 & .75 & & & & \\
\hline & ETO5 & .82 & .67 & & & & \\
\hline
\end{tabular}


Table 4.1: Loadings, Reliability and Convergent Validity Values (con't)

\begin{tabular}{cccccccc}
\hline \hline Variables & Items & Loading & $\begin{array}{c}\text { Indicator } \\
\text { Reliability }\end{array}$ & $\begin{array}{c}\text { Cronbach's } \\
\text { Alpha }\end{array}$ & CR & AVE & $\begin{array}{c}\text { Discriminant } \\
\text { Validity? }\end{array}$ \\
\hline & ETO6 & $\mathbf{. 7 1}$ & .50 & & & & \\
& ETO7 & $\mathbf{. 8 2}$ & .67 & & & \\
& ETO8 & $\mathbf{. 8 1}$ & .66 & & & & \\
& ETO9 & $\mathbf{. 7 4}$ & .55 & & & \\
AF & FAF1 & $\mathbf{. 6 7}$ & .45 & & & \\
& FAF2 & $\mathbf{. 8 6}$ & .73 & .84 & .52 & \\
& FAF3 & $\mathbf{. 6 7}$ & .45 & .77 & & & \\
\hline \hline
\end{tabular}

Notes: FP=Firm Performance, EO=Entrepreneurial Orientation, $\mathrm{MO}=$ Market Orientation, $\mathrm{LO}=$ Learning Orientation, $\mathrm{TO}=\mathrm{Technology}$ Orientation, $\mathrm{AF}=\mathrm{Access}$ to Finance.

Figure 4.1: Measurement Model

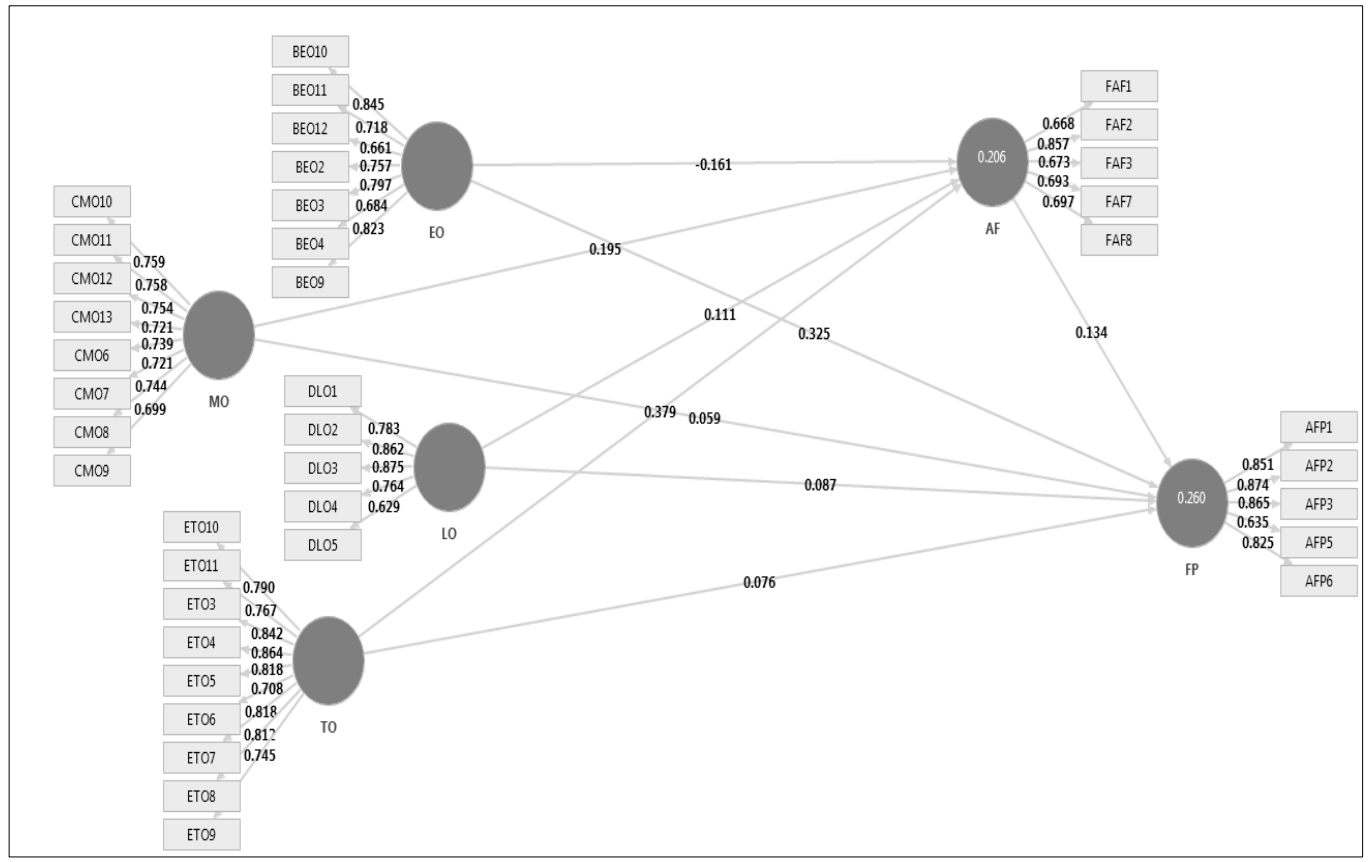

In this study, internal consistency reliability was assessed by examining CR. Therefore, in this study, composite reliability and Cronbach's alpha values for all the constructs were examined, and the results in Table 4.1 show that all CR and Cronbach's alpha values exceed the recommended threshold value of 0.70 (Hair Jr. et al., 2013; Henseler, Ringle, \& Sinkovics, 2009). The CR values in this study ranges between 0.84 to 0.94 , indicating the reliability of the measurement model. 
With regards to identifying an element of convergence in the measurements of the construct, AVE was used with a threshold value of 0.50 and above (Henseler et al., 2009). Therefore, results in Table 4.1 show that the AVE value of all the constructs exceed the threshold value of 0.50 . The result reveals AVE values range from 0.54 to 0.66 ; so it can be concluded that convergent validity is established.

Then, discriminant validity was considered, which concerns the extent to which one construct is actually different from another construct (Hair Jr. et al., 2013). The most conventional approach in assessing discriminant validity is Fornell-Larcker Criterion (Hair Jr. et al., 2013). Therefore, in this study, discriminant validity was assessed by comparing the square root of the AVE for each construct with the correlations presented in the correlation matrix. Table 4.2 shows the results of Fornell-Larcker Criterion assessment with the square root of the constructs. The AVE in bold is greater than its highest construct's correlation with any other constructs. Thus, it is concluded that discriminant validity on the construct has been established (Hair Jr. et al., 2013; Henseler et al., 2009).

Table 4.2: Discriminant Validity

\begin{tabular}{ccccccc}
\hline \hline Variables & FP & TO & LO & EO & MO & AF \\
\hline FP & $\mathbf{. 8 1}$ & & & & & \\
TO & .41 & $\mathbf{. 8 0}$ & & & & \\
LO & .18 & .24 & $\mathbf{. 7 9}$ & & & \\
EO & .46 & .68 & .10 & $\mathbf{. 7 6}$ & & \\
MO & .40 & .60 & .21 & .73 &. $\mathbf{7 4}$ & \\
AF & .29 & .40 & .21 & .25 & .33 & $\mathbf{. 7 2}$ \\
\hline \hline
\end{tabular}

Note: The bold values represent the square root of Average Variance Extracted (AVE).

Lastly, in this study, outer factor loading as important criteria in assessing indicator's contribution to assigned construct was examined. Outer loadings were examined based on the threshold value of 0.50 and above (Hair Jr. et al., 2010). However, Hair Jr. et al. (2013) stressed that outer loading greater than 0.40 but less than 0.70 should be carefully analyzed and should be deleted only if it increases the value of CR and AVE. Table 4.3 indicates that all the bold values of the loading exceed the suggested threshold of 0.50 and above, showing satisfactory contribution of the indicators to assigned constructs. Additionally, as argued by Hair Jr. et al., (2013), discriminant validity can be assessed by examining the indictors' outer loadings. They argue that discriminant validity can be established when the indicator's outer loading on a construct is higher than all its cross-loading with other constructs. Hence, Table 4.3 indicates absence of discriminant validity problem since the loadings are greater than 0.5 , and no any other indicator has loading more than the one it intends to measure. 
Table 4.3: Factor loading and Cross-loading

\begin{tabular}{|c|c|c|c|c|c|c|}
\hline "Items & FP & 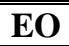 & "MO & $\overline{~ L O}$ & $\overline{~ T O}$ & $\overline{\mathbf{A F}}$ \\
\hline AFP1 & .85 & .40 & .33 & .19 & .36 & .25 \\
\hline AFP2 & .87 & .37 & .29 & .15 & .33 & .25 \\
\hline AFP3 & .87 & .40 & .37 & .12 & .41 & .27 \\
\hline AFP5 & .63 & .30 & .30 & .13 & .21 & .16 \\
\hline AFP6 & .82 & .40 & .36 & .15 & .33 & .23 \\
\hline BEO10 & .37 & .85 & .62 & .06 & .52 & .20 \\
\hline BEO11 & .35 & .72 & .54 & .00 & .44 & .24 \\
\hline BEO12 & .35 & .66 & .44 & .18 & .53 & .15 \\
\hline $\mathrm{BEO} 2$ & .40 & .76 & .55 & .12 & .62 & .20 \\
\hline BEO3 & .38 & .80 & .56 & .01 & .53 & .15 \\
\hline BEO4 & .24 & .68 & .50 & .07 & .45 & .15 \\
\hline BEO9 & .33 & .82 & .61 & .07 & .49 & .21 \\
\hline CMO10 & .32 & .49 & .76 & .13 & .45 & .29 \\
\hline CMO11 & .25 & .48 & .76 & .11 & .44 & .22 \\
\hline CMO12 & .30 & .43 & .75 & .17 & .43 & .27 \\
\hline CMO13 & .32 & .49 & .72 & .24 & .50 & .23 \\
\hline CMO6 & .32 & .59 & .74 & .12 & .39 & .23 \\
\hline CMO7 & .25 & .62 & .72 & .15 & .43 & .21 \\
\hline CMO8 & .31 & .61 & .74 & .19 & .44 & .25 \\
\hline CMO9 & .28 & .57 & .70 & .13 & .44 & .21 \\
\hline DLO1 & .11 & .05 & .13 & .78 & .14 & .11 \\
\hline DLO2 & .14 & .07 & .17 & .86 & .21 & .21 \\
\hline DLO3 & .18 & .11 & .19 & .87 & .26 & .20 \\
\hline DLO4 & .17 & .06 & .16 & .76 & .22 & .21 \\
\hline DLO5 & .09 & .08 & .18 & .63 & .10 & .15 \\
\hline ETO10 & .31 & .57 & .42 & .17 & .79 & .37 \\
\hline ETO11 & .29 & .57 & .42 & .15 & .77 & .28 \\
\hline ETO3 & .35 & .58 & .47 & .26 & .84 & .38 \\
\hline ETO4 & .37 & .62 & .53 & .17 & .86 & .36 \\
\hline ETO5 & .37 & .60 & .58 & .14 & .82 & .36 \\
\hline ETO6 & .28 & .37 & .44 & .34 & .71 & .36 \\
\hline ETO7 & .33 & .57 & .46 & .12 & .82 & .23 \\
\hline ETO8 & .29 & .56 & .48 & .11 & .81 & .23 \\
\hline ETO9 & .33 & .41 & .46 & .29 & .75 & .34 \\
\hline FAF1 & .21 & .24 & .26 & .01 & .25 & .67 \\
\hline FAF2 & .25 & .23 & .32 & .21 & .34 & .86 \\
\hline FAF3 & .21 & .13 & .17 & .13 & .26 & .67 \\
\hline FAF7 & .13 & .15 & .13 & .12 & .22 & .69 \\
\hline FAF8 & .20 & .15 & .25 & .28 & .37 & .70 \\
\hline
\end{tabular}

Note. The bold values indicate the items that belong to the column's construct. 


\subsubsection{The Structural Model}

As mentioned earlier, once the measurement model (outer model) was examined and the reliability and validity of the model established, the next step was to evaluate the outer model (structural model) results. This involved assessing the outer model's predictive abilities and the relationships between the constructs. As suggested by Hair Jr. et al. (2013), before assessing the structural model, collinearity should be examined. The results show that there is no collinearity among the predictor constructs in the structural model as the VIF values are clearly below the threshold of 5 .

According to Hair Jr. et al. (2013), the key criteria for assessing the structural model in PLS-SEM are the significance of the path coefficients, coefficient determination $\left(\mathrm{R}^{2}\right)$, the effect size $\left(\mathrm{f}^{2}\right)$ and predictive relevance $\left(\mathrm{Q}^{2}\right)$. Mediation analysis assesses the indirect effect of the independent variable on the dependent variable via an intervening variable. However, Preacher and Hayes (2008) observe that the techniques for assessing mediation are numerous, however, the most recent mediation analysis approach is the bootstrapping method. Where the bootstrapping generates an empirical representation of the distribution of the sample of the indirect effect (Rucker, Preacher, Tormala, \& Petty, 2011).

The justification and advantages of bootstrapping method to test mediation have been highlighted by several studies, such as (Hair Jr. et al., 2013; Hayes \& Preacher, 2010). Hayes and Preacher (2010) and Preacher and Hayes (2008) conclude that the main advantage of bootstrapping approach is that it does not require any assumptions about the sampling distributions of the indirect effect or its product. Knowing the advantage of bootstrapping method over other methods, Hair Jr. et al., (2013) and Hayes and Preacher (2010) suggest testing the significance of the mediation using bootstrapping methods. Hence, this study tested the mediating role of access to finance on the influence of EO, MO, LO, and TO on firm performance with SmartPLS 3.0 with 362 cases and 5,000 subsamples. It is therefore clear from Table 4.5 that access to finance mediates the relationship between MO and firm performance $(\beta .03 ; \mathrm{t}=1.67 ; \mathrm{p}<.05) ; \mathrm{LO}$ and firm performance $(\beta .02 ; \mathrm{t}=1.75 ; \mathrm{p}<.05)$; and TO and firm performance $(\beta .05 ; \mathrm{t}=2.19 ; \mathrm{p}<.01)$. However, Table 4.4 shows that access to finance does not mediate the relationship between EO and firm performance $(\beta .-02 ; \mathrm{t}=-1.36 ; \mathrm{p}<.1)$.

Table 4.4: Results of Mediation Test

\begin{tabular}{ccccccc}
\hline \hline \multicolumn{2}{c}{ Hypotheses/Paths } & $\begin{array}{c}\text { Path } \\
\text { Coefficient }\end{array}$ & $\begin{array}{c}\text { Standard } \\
\text { Error }\end{array}$ & $\begin{array}{c}\text { T- } \\
\text { Statistics }\end{array}$ & P-Value & Decision \\
\hline $\mathrm{H} 1$ & $\mathrm{EO} \rightarrow \mathrm{AF} \rightarrow \mathrm{FP}$ & -.02 & .02 & -1.36 & .91 & Not Supported \\
$\mathrm{H} 2$ & $\mathrm{MO} \rightarrow \mathrm{AF} \rightarrow \mathrm{FP}$ & $.03 * *$ & .02 & 1.67 & .05 & Supported \\
$\mathrm{H} 3$ & $\mathrm{LO} \rightarrow \mathrm{AF} \rightarrow \mathrm{FP}$ & $.02 * *$ & .01 & 1.75 & .04 & Supported \\
$\mathrm{H} 4$ & $\mathrm{TO} \rightarrow \mathrm{AF} \rightarrow \mathrm{FP}$ & $.05 * * *$ & .02 & 2.19 & .01 & Supported \\
\hline \hline
\end{tabular}

Notes: $*: \mathrm{p}<0.1 ; * *: \mathrm{p}<0.05 ; * * *: \mathrm{p}<0.01$. 
Figure 4.2: Structural Model

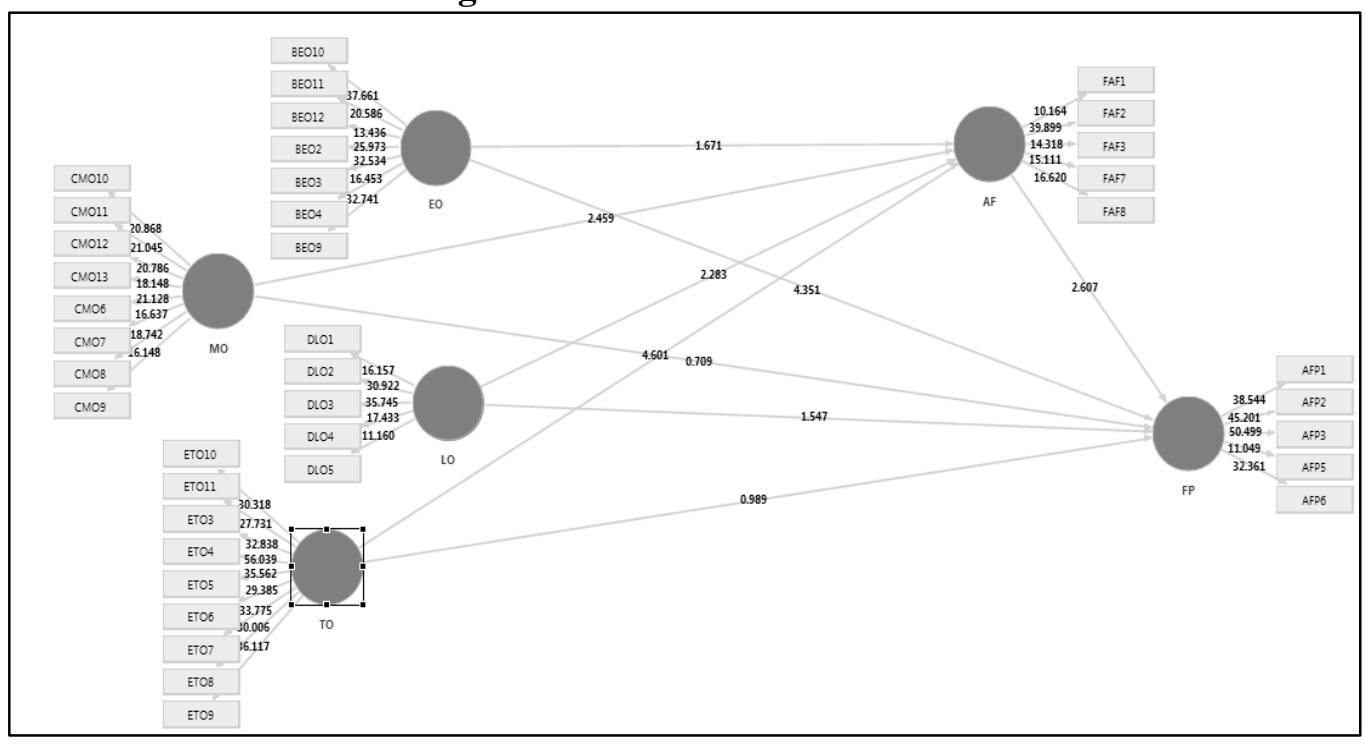

According to Cohen (1988), $\mathrm{R}^{2}$ values of $.27, .13$ and .02 indicate substantial, moderate and weak, respectively. Results in Figure 4.1 show that the $\mathrm{R}^{2}$ value of access to finance (.21) is moderate and firm performance (.27) is slightly substantial. This $\mathrm{R}^{2}$ value is higher than the one reported by Hakala (2013) and Mahmoud and Yusif (2012), respectively.

It follows that the $\mathrm{R}^{2}$ value indicates all the four exogenous variables (EO, MO, LO, and TO) combined together in the model explain $21 \%$ variance in the mediating variable access to finance. Similarly, the holistic $\mathrm{R}^{2}$ value indicates that all the six exogenous variables (EO, MO, LO, TO, access to finance and business environment) combined together in the model explain $27 \%$ variance in the endogenous variable (firm performance). Consequently, based on the assessment of the $\mathrm{R}^{2}$ of the endogenous latent variables firm performance $(.27)$ and access to finance $(.21)$, it is concluded that the model has substantial predictive validity.

Having assessed the coefficient of determination of the endogenous constructs (access to finance and firm performance), the next criterion assesses the effect size $\left(\mathrm{f}^{2}\right)$ as suggested by Hair Jr. et al. (2013). The threshold of 0.02, 0.15, and 0.35 have been proposed as small, moderate and large effects, respectively (Cohen, 1988). However, Chin, Marcolin and Newsted (2003), stress that even the tiniest strength of $\mathrm{f}^{2}$ should be considered as it can influence the endogenous variables. In this study, the effect size for the exogenous construct found to be statistically significant to affect the endogenous variables are assessed and reported. The result in Table 4.5 shows the effect size of the particular exogenous construct on the respective endogenous construct. The result indicates that 
most of the exogenous constructs have small effect size on their respective endogenous construct.

Table 4.5: Effect Size $\left(\mathrm{f}^{2}\right)$

\begin{tabular}{ccc}
\hline \hline Variables & Effect Size & \\
\hline EO-FP & .05 & Small \\
MO-FP & .00 & - \\
LO-FP & .01 & Small \\
TO-FP & .00 & - \\
AF-FP & .02 & Small \\
EO-AF & .01 & Small \\
MO-AF & .02 & Small \\
LO-AF & .01 & Small \\
TO-AF & .09 & Small \\
\hline \hline
\end{tabular}

Finally the predictive relevance $\mathrm{Q}^{2}$ assessment which can be carried out using StoneGeisser's $\mathrm{Q}^{2}$ test and measured using blindfolding procedures (Hair Jr. et al., 2013; Henseler et al., 2009). Therefore, this study used Stone-Geisser test to assess the $\mathrm{Q}^{2}$, through blindfolding procedure to obtain the cross-validated redundancy measure for endogenous latent construct (Hair Jr. et al., 2013). Table 4.6 presents the cross-validated redundancy for access to finance and firm performance. The result shows that all the $\mathrm{Q}^{2}$ values are greater than zero access to finance (.10) and firm performance (.16); this suggests a substantial predictive relevance of the model. This is in line with the suggestion by Hair Jr. et al. (2013) and Henseler et al. (2009) that $\mathrm{Q}^{2}$ values greater than zero indicate the model has predictive relevance, while $\mathrm{Q}^{2}$ values less than zero, indicate the model lacks predictive relevance.

Table 4.6: Predictive Relevance $\left(\mathrm{Q}^{2}\right)$

\begin{tabular}{cccc}
\hline \hline Total & SSO & SSE & 1-SSE/SSO \\
\hline AF & 1810.00 & 1641.22 & .10 \\
FP & 1810.00 & 1514.54 & .16 \\
\hline \hline
\end{tabular}

Note: $\mathrm{FP}=$ Firm Performance, $\mathrm{AF}=\mathrm{Access}$ to Finance.

\section{DISCUSSION}

The objective for this study is to examine the mediating role of access to finance on the positive relationship between EO, MO, LO, TO and performance of SMEs in Nigeria. So, four mediating hypotheses were proposed and tested using bootstrapping method (Preacher \& Hayes, 2008). Precisely, hypotheses H1, H2, H3 and H4 were tested to see the mediating role of access to finance.

In order to attain this essential objective, $\mathrm{H} 1$ was tested which states that access to finance mediates the positive relationship between EO and performance of SMEs in Nigeria. The 
statistical result indicates that access to finance does not mediate the relationship between EO and firm performance. This result, however, is not surprising given the fact that the path from EO to access to finance was inversely significant in the direct relationship. Hence, $\mathrm{H} 1$ is not supported. A plausible reason for this is that the more SMEs perceive high environmental risk, the less they engage in profitable business. In other words, high EO means high risk that requires significant amount of financial resources rather than generating the resources. Therefore, the role of financial resources in explaining the relationship may not be noteworthy.

Secondly, $\mathrm{H} 2$ states that access to finance mediates the positive relationship between MO and performance of SMEs in Nigeria. However, in this study, MO did not significantly affect firm performance directly, but it has a direct and positive impact on the access to finance. Interestingly, the result shows that MO affects firm performance through access to finance. In other words, the relationship has good magnitude and is significant due to the mediation role of access to finance. In summary, based on the present study's results, the influence of MO on firm performance is better understood through the mediational role of access to finance. Hence, $\mathrm{H} 2$ is supported. In this case, the result demonstrates that SMEs' ability to attract, retain more customers and deal with competition, lead to improvements in their financial resource access, and consequently to achieving higher performance. This seems to indicate that firm performance depends on MO when firms have access to finance. The finding concurs with the past research (Huhtala et al., 2014; Mahmoud \& Yusif, 2012) which shows that MO is related to firm performance through some mediating variables.

Thirdly, $\mathrm{H} 3$ is supported as the result establishes that access to finance mediates the relationship between $\mathrm{LO}$ and firm performance. According to this finding, implementing LO will help SMEs to increase their financial accessibility and in turn improve firm performance. This result also shows that no matter how much a firm is learning oriented, or good in using information, it cannot assure firm performance if it cannot get access to enough financial capital. Moreover, this explains that although a large number of SMEs are looking for better performance, few of them perform sufficiently. This is because they refuse to acknowledge that their strategies are essential to getting financing. Moreover, this finding shows that SMEs can use learning to increase their financial resources and improve performance.

Lastly, $\mathrm{H} 4$ is also supported as the result indicates that the mediatory role of access to finance between TO and firm performance relationship is quite significant. This sheds more light that TO facilitate SMEs' ability to generate more financial resources that can lead to firm performance. To this end, the results of this study suggest that SMEs in Nigeria need to be technology oriented which will lead them to better access to finance and superior performance. 
Conclusively, the study shows that the strategic orientations (MO, LO and TO) indirectly explain firm performance through access to finance. This is important additional explanation for the existence of the relationship between these strategic orientations and firm performance. The results further suggest that SMEs need to use their strategic activities to improve their ability to obtain finances in order to perform well. While strategic orientations appear as viable predictors of firm performance, the evidence suggests that SMEs, combining it with other orientations, have higher access to finance and perform much better. Consistent with the RBV, the findings suggest that strategic orientations are culture-based, valuable and sophisticated firm resources that can lead to competitive advantages.

The study is subject to the usual limitations with cross-sectional, quantitative research design, single informant (owner-manager) and regional bias. Future studies should use longitudinal study and combine both quantitative and qualitative methods. Additionally, future studies should collect data from multiple participants (owners, managers and financiers) separately per enterprise. Finally, this study examined the mediating role of access to finance on the relationship between $\mathrm{EO}, \mathrm{MO}, \mathrm{LO}, \mathrm{TO}$ and performance of SMEs in Nigeria. The independent variables tested in the study were confined to SMEs' performance. Other factors that belong to a firm's strategic resources, such as employee orientation, cost orientation and network orientation can be used to extend the framework proposed in the study. Future researchers could further broaden the scope of this study by conducting a configurational approach (three-way interaction model) to explain the variance in performance.

\section{REFERENCES}

Al-dhaafri, H. S., \& Al-swidi, A. K. (2014). The entrepreneurial orientation and the organizational performance: Does enterprise resource planning have a mediating role: A study on Dubai police. Paper presented at the 9th International Business and Social Science Research Conference. Dubai, UAE.

Alegre, J., \& Chiva, R. (2009). Entrepreneurial orientation, organizational learning capability and performance in the ceramic tiles industry. Instituto Valenciano de Investigaciones Económicas Working Paper Series No. WP-EC 2009-08.

Aminu, I. M., \& Shariff, M. N. M. (2014). Mediating role of access to finance on the relationship between strategic orientation and smes performance in Nigeria: A proposed research framework. International Journal of Management Research \& Review, 4(11), 1023-1035.

Aminu, I. M., \& Shariff, M. N. M. (2015). Influence of strategic orientation on SMEs access to finance in Nigeria. Asian Social Science, 11(4), 298-309.

Aziz, R. A., Mahmood, R., Tajudin, A., \& Abdullah, M. H. (2014). The relationship between entrepreneurial orientation and business performance of SMEs in Malaysia. International Journal of Management Excellence, 2(3), 221-226. 
Baker, W. E., \& Sinkula, J. M. (1999). Learning orientation, market orientation, and innovation: Integrating and extending models of organizational performance. Journal of Market-Focused Management, 4(4), 295-308.

Baker, W. E., \& Sinkula, J. M. (2009). The complementary effects of market orientation and entrepreneurial orientation on profitability in small businesses. Journal of Small Business Management, 47(4), 443-464.

Barney, J. (1991). Firm resources and sustained competitive advantage. Journal of Management, 17(1), 99-120.

Bouri, A., Breij, M., Diop, M., Kempner, R., Klinger, B., \& Stevenson, K. (2011). Report on support to SMEs in developing countries through financial intermediaries. Geneva: Dalberg Global Development Advisors 2011.

Brouthers, K. D., Nakos, G., \& Dimitratos, P. (2014). SME entrepreneurial orientation, international performance, and the moderating role of strategic alliances. Entrepreneurship: Theory and Practice, 1-27.

Cheng, B., Ioannou, I., \& Serafeim, G. (2014). Corporate social responsibility and access to finance. Strategic Management Journal, 35(1), 1-23.

Chin, W. W., Marcolin, B. L., \& Newsted, P. R. (2003). A partial least squares latent variable modeling approach for measuring interaction effects: Results from a Monte Carlo simulation study and an electronic-mail emotion/adoption study. Information Systems Research, 14(2), 189-217.

Churchill, G. A. (1979). A paradigm for developing better measures of marketing constructs. Journal of Marketing Research, XVI, 64-73.

Cohen, J. (1988). Statistical power analysis for the behavioral sciences (2nd ed.). London: Lawrence Erlbaum Associates Publishers.

Covin, J. G., \& Miller, D. (2014). International entrepreneurial orientation: Conceptual considerations, research themes, measurement issues, and future research directions. Entrepreneurship Theory and Practice, 38(1), 11-44.

Covin, J. G., \& Slevin, D. P. (1989). Strategic management of small firms in hostile and benign environments. Strategic Management Journal, 10(1), 75-87.

Dauda, Y. A., \& Akingbade, W. A. (2010). Employee's market orientation and business performance in Nigeria: Analysis of small business enterprises in Lagos state. International Journal of Marketing Studies, 2(2), 134-143.

Demir, F., \& Caglayan, M. (2012). Firm productivity, exchange rate movements, sources of finance and export orientation. MPRA Paper Working Paper No. 37397.

Deshpandé, R., Farley, J. U., \& Webster, F. E. (1993). Corporate culture, customer orientation, and innovativeness in a Japanese firms: A quadrad analysis. Journal of Marketing, 57(1), 23-37.

Dillman, D. A. (2007). Mail and internet surveys: The tailored design method $\left(2^{\text {nd }}\right.$ edition., Vol. 2). New York: John Wiley \& Sons, Inc.

Eris, E. D., \& Ozmen, O. N. T. (2012). The effect of market orientation, learning orientation and inovativeness on firm performance: A research from Turkish logistics sector. International Journal of Economic Sciences and Applied Research, 5(1), 77-108.

Ettlie, J. E., Bridges, W. P., \& O'keefe, R. D. (1984). Organization strategy and structural differences for radical versus incremental innovation. Management Science, 30(6), 682-695. 
Farrell, M. A. (2000). Developing a market oriented learning organisation. Australian Journal of Management, 25(2), 201-222.

Farrell, M. A., Oczkowski, E., \& Kharabsheh, R. (2008). Market orientation, learning orientation and organisational performance in international joint ventures. Asia Pacific Journal of Marketing and Logistics, 20(3), 289-308.

Farrell, M., \& Mavondo, F. T. (2004). The effect of downsizing strategy and reorientation strategy on a learning orientation. Personnel Review, 33(4), 383-402.

Fatoki, O. (2012). The impact of entrepreneurial orientation on access to debt finance and performance of small and medium enterprises in South Africa. Journal of Social Science, 32(2), 121-131.

Frank, H., Kessler, A., \& Fink, M. (2010). Entrepreneurial orientation and business performance-A replication study. Schmalenbach Business Review, 62, 175-198.

Gao, G. Y., Zhou, K. Z., \& Yim, C. K. B. (2007). On what should firms focus in transitional economies? A study of the contingent value of strategic orientations in China. International Journal of Research in Marketing, 24(1), 3-15.

Gatignon, H., \& Xuereb, J.-M. (1997). Strategic orientation of the firm and new product performance. Journal of Marketing Research, XXXIV, 77-90.

Grawe, S. J., Chen, H., \& Daugherty, P. J. (2009). The relationship between strategic orientation, service innovation, and performance. International Journal of Physical Distribution \& Logistics Management, 39(4), 282-300.

Hair Jr., J. F., Black, J. W., Babin, B. J., \& Anderson, E. R. (2010). Multivariate data analysis (Seventh Ed.). Edinburgh: Pearson Education Limited.

Hair Jr., J. F., Hult, G. T. M., Ringle, C., \& Sarstedt, M. (2013). A primer on partial least squares structural equation modeling (PLS-SEM). USA: SAGE Publications.

Hakala, H. (2013). Entrepreneurial and learning orientation: Effects on growth and profitability in the software sector. Baltic Journal of Management, 8(1), 102-118.

Hakala, H., \& Kohtamaki, M. (2010). The interplay between orientations: Entrepreneurial, technology and customer orientations in software companies. Journal of Enterprising Culture, 18(3), 265-290.

Hakala, H., \& Kohtamaki, M. (2011). Configurations of entrepreneurial, customer and technology orientation: Differences in learning and performance of software companies. International Journal of Entrepreneurial Behaviour \& Research, 17(1), 64-81.

Hayes, A. F., \& Preacher, K. J. (2010). Quantifying and testing indirect effects in simple mediation models when the constituent paths are nonlinear. Multivariate Behavioral Research, 45(4), 627-660.

Henseler, J., Ringle, C. M., \& Sinkovics, R. R. (2009). The use of partial least squares path modeling in international marketing. New Challenges to International Marketing Advances in International Marketing, 20, 277-319.

Hoq, M. (2009). Innovativeness: Its antecedents and impact on SME business performance. International Journal of Business and Management, 4(11), 100110.

Hortinha, P., Lages, C., \& Lages, L. F. (2011). The Trade-Off Between Customer and Technology Orientations : and Export Performance. Journal of International Marketing, 19(3), 36-58. 
Hughes, M., \& Morgan, R. E. (2007). Deconstructing the relationship between entrepreneurial orientation and business performance at the embryonic stage of firm growth. Industrial Marketing Management, 36(5), 651-661.

Huhtala, J.-P., Sihvonen, A., Frösén, J., Jaakkola, M., \& Tikkanen, H. (2014). Market orientation, innovation capability and business performance. Baltic Journal of Management, 9(2), 134-152.

Hult, G. T. M., Ketchen, D. J., \& Slater, S. F. (2005). Market orientation and performance: An integration of disparate approaches. Strategic Management Journal, 26(12), 1173-1181.

Hurley, R. F., \& Hult, G. T. M. (1998). Innovation, market orientation, and organizational learning: An integration and empirical examination. The Journal of Marketing, $62(3), 42-54$.

Idar, R., \& Mahmood, R. (2011). Entrepreneurial and marketing orientation relationship to performance: The SME Perspective. Interdisciplinary Review of Economics and Management, 1(2), 1-8.

Jaworski, B. J., \& Kohli, A. K. (1993). Market orientation: Antecedents and consequences. The Journal of Marketing, 57(3), 53-70.

Jiménez-Jiménez, D., \& Sanz-Valle, R. (2011). Innovation, organizational learning, and performance. Journal of Business Research, 64(4), 408-417.

Jiménez-Jimenez, D., Valle, R. S., \& Hernandez-Espallardo, M. (2008). Fostering innovation: The role of market orientation and organizational learning. European Journal of Innovation Management, 11(3), 389-412.

Kara, A., Spillan, J. E., \& DeShields Jr., O. W. (2005). The effect of a market orientation on business performance: A study of small sized service retailers using MARKOR scale. Journal of Small Business Management, 43(2), 105-118.

Kohli, A. K., \& Jaworski, B. J. (1990). Market orientation: The construct, research propositions, and managerial implications. Journal of Marketing, 54(2), 1-18.

Kraus, S. (2013). The role of entrepreneurial orientation in service firms: Empirical evidence from Austria. The Service Industries Journal, 33(5), 427-444.

Kropp, F., Lindsay, N. J., \& Shoham, A. (2006). Entrepreneurial, market, and learning orientations and international entrepreneurial business venture performance in South African firms. International Marketing Review, 23(5), 504-523.

Lafferty, B. A., \& Hult, G. T. M. (2001). A synthesis of contemporary market orientation perspectives. European Journal of Marketing, 35(1/2), 92-109.

Laukkanen, T., Nagy, G., Hirvonen, S., Reijonen, H., \& Pasanen, M. (2013). The effect of strategic orientations on business performance in SMEs: A multigroup analysis comparing Hungary and Finland. International Marketing Review, 30(6), 510 535.

Long, H. C. (2013). The relationship among learning orientation, market orientation, entrepreneurial orientation, and firm performance of Vietnam marketing communications firms. Philippine Management Review, 20, 37-46.

Lowry, P. B., \& Gaskin, J. (2014). Partial Least Squares (PLS) Structural Equation Modeling (SEM) for building and testing behavioral causal theory: When to choose it and how to use it. IEEE Transactions on Professional Communication, 57(2), 123-146. 
Lumpkin, G. T., \& Dess, G. G. (1996). Clarifying the entrepreneurial orientation construct and linking it to performance. Academy of Management Review, 21(1), 135-172.

Lumpkin, G. T., \& Dess, G. G. (2001). Linking two dimensions of entrepreneurial orientation to firm performance: The moderating role of environment and industry life cycle. Journal of Business Venturing, 16(5), 429-451.

Mahmoud, M. A. (2011). Market orientation and business performance among SMEs in Ghana. International Business Research, 4(1), 241-251.

Mahmoud, M. A., \& Yusif, B. (2012). Market orientation, learning orientation, and the performance of nonprofit organisations (NPOs). International Journal of Productivity and Performance Management, 61(6), 624-652.

Martin, K. D., Cullen, J. B., Johnson, J. L., \& Parboteeah, K. P. (2007). Deciding to Bribe: A Cross-Level analysis of firm and home country influences on bribery activity. Academy of Management Journal, 50(6), 1401-1422.

Mavondo, F. T., Chimhanzi, J., \& Stewart, J. (2005). Learning orientation and market orientation: Relationship with innovation, human resource practices and performance. European Journal of Marketing, 39(11/12), 1235-1263.

Miller, D. (1983). The correlates of entrepreneurship in three types of firms. Management Science, 29(7), 770-791.

Mohammed, U. D., \& Obeleagu-nzelibe, C. G. (2014). Entrepreneurial skills and profitability of Small and Medium Enterprises (SMEs): Resource acquisition strategies for new ventures in Nigeria. Paper presented at the 25th International Business Research Conference, Cape Town.

Moullin, M. (2007). Performance measurement definitions: Linking performance measurement and organisational excellence. International Journal of Health Care Quality Assurance, 20(3), 181-183.

$\mathrm{Mu}$, J., \& Di Benedetto, C. A. (2011). Strategic orientations and new product commercialization: Mediator, moderator, and interplay. $R \& D$ Management, 41(4), 337-359.

Mutlu, H. M., \& Aksoy, H. (2014). Strategic orientations, firm capabilities, and export performance: An empirical analysis in Turkey. International Journal of Economic Practices and Theories, 4(2), 214-221.

Narver, J. C., \& Slater, S. F. (1990). The effect of a market orientation on business profitability. Journal of Marketing, 54(4), 20-35.

Ndumanya, N. (2013). Why SMEs' contribution to the nation's GDP is poor. BusinessDay. Lagos, Nigeria.

Neely, A., Gregory, M., \& Platts, K. (1995). Performance measurement system design: A literature review and research agenda. International Journal of Operations \& Production Management, 15(4), 80-116.

Nikoomaram, H., \& Ma'atoofi, A. R. (2011). The effect of learning orientation on market orientation and performance in small sized firms: Evidence from Iran. European Journal of Social Sciences, 18(4), 632-642.

Paladino, A. (2007). Investigating the drivers of innovation and new product success: A comparison of strategic orientations. Journal of Product Innovation Management, 24(6), 534-553. 
Podsakoff, P. M., MacKenzie, S. B., Lee, J.-Y., \& Podsakoff, N. P. (2003). Common method biases in behavioral research: A critical review of the literature and recommended remedies. The Journal of Applied Psychology, 88(5), 879-903.

Polat, İ., \& Mutlu, H. M. (2012). The impacts of market orientation, entrepreneurial orientation, environmental uncertainty and internationalization speed on firm performance. European Researcher, 27(8-2), 1248-1254.

Preacher, K. J., \& Hayes, A. F. (2008). Asymptotic and resampling strategies for assessing and comparing indirect effects in multiple mediator models. Behavior Research Methods, 40(3), 879-891.

Rauch, A., Wiklund, J., Lumpkin, G. T., \& Frese, M. (2009). Entrepreneurial orientation and business performance: An assessment of past research and suggestions for the future. Entrepreneurship Theory and Practice, 33(3), 761-787.

Ringle, C. M., Wande, S., \& Becker, J. M. (2014, December 29). Smartpls 3.0. Hamburg: SmartPLS. Retrieved from http://www.smartpls.com

Roxas, B., \& Chadee, D. (2013). Effects of formal institutions on the performance of the tourism sector in the Philippines: The mediating role of entrepreneurial orientation. Tourism Management, 37, 1-12.

Rucker, D. D., Preacher, K. J., Tormala, Z. L., \& Petty, R. E. (2011). Mediation analysis in social psychology: Current practices and new recommendations. Social and Personality Psychology Compass, 5(6), 359-371.

Ruekert, R. W. (1992). Developing a market orientation: An organizational strategy perspective. International Journal of Research in Marketing, 9(3), 225-245.

Salavou, H. (2010). Do customer and technology orientations influence product innovativeness in SMEs? Some new evidence from Greece. Journal of Marketing Management, 21(3-4), 307-338.

Salkind, N. J. (1997). Exploring Research ( $3^{\text {rd }}$ edition.). Upper Saddle River, NJ: Prentice Hall.

Sandberg, K. W. (2003). An exploratory study of women in micro enterprises: genderrelated differences. Journal of Small Business and Enterprise Development, 10(4), 408-417.

Saunders, M., Lewis, P., \& Thornhill, A. (2009). Research methods for business students $\left(5^{\text {th }}\right.$ edition.). India: Pearson Education.

Sekaran, U., \& Bougie, R. (2010). Research methods for business: A skill building approach $\left(5^{\text {th }}\right.$ edition.). United Kindom: John Wiley \& Sons Ltd.

Shapiro, B. P. (1988). What the hell is market oriented? Harvard Business School: Harvard Business Review Reprints.

Slater, S. F., \& Narver, J. C. (1995). Market orientation and the learning organization. The Journal of Marketing, 59(3), 63-74.

SMEDAN. (2012). Survey report on Micro, Small, and Medium Enterprises (MSMEs) in Nigeria. Abuja: Small and Medium Enterprises Development Agency of Nigeria.

Spanjol, J., Qualls, W. J., \& Rosa, J. A. (2011). How many and what kind? The role of strategic orientation in new product ideation. Journal of Product Innovation Management, 28(2), 236-250.

Stam, W., \& Elfring, T. (2008). Entrepreneurial orientation and new venture performance: The moderating role of intra-and extraindustry social capital. Academy of Management Journal, 51(1), 97-111. 
Su, Z., Xie, E., \& Li, Y. (2011). Entrepreneurial orientation and firm performance in new ventures and established firms. Journal of Small Business Management, 49(4), $558-577$.

Suliyanto, S., \& Rahab, R. (2012). The role of market orientation and learning orientation in improving innovativeness and performance of small and medium enterprises. Asian Social Science, 8(1), 134-145.

Turyahebwa, A., Sunday, A., \& Ssekajugo, D. (2013). Financial management practices and business performance of small and medium enterprises in western Uganda. African Journal of Business Management, 7(38), 3875-3885.

Voss, G. B., \& Voss, Z. G. (2000). Strategic orientation and firm performance in an artistic environment. The Journal of Marketing, 64(1), 67-83.

Wang, C.-H., Chen, K.-Y., \& Chen, S.-C. (2012). Total quality management, market orientation and hotel performance: The moderating effects of external environmental factors. International Journal of Hospitality Management, 31(1), $119-129$.

Wiklund, J., \& Shepherd, D. (2005). Entrepreneurial orientation and small business performance: A configurational approach. Journal of Business Venturing, 20(1), 71-91.

Zahra, S. A., \& Covin, J. G. (1995). Contextual influences on the corporate entrepreneurship-performance relationship: A longitudinal analysis. Journal of Business Venturing, 10(1), 43-58. 